\title{
ІННОВАЦЙНІ ШЛЯХИ ФОРМУВАННЯ КОМПЕТЕНТНОСТІ САМООСВІТИ СТУДЕНТІВ У НАВЧАЛЬНОМУ ПРОЦЕСІ ПЕДАГОГІЧНОГО УНІВЕРСИТЕТУ
}

Кисельова О. Б. Інноваційні шляхи формування компетентності самоосвіти студентів у навчальному процесі педагогічного університету.

У статті розглянуто сутність, структуру компетентності самоосвіти майбутнього педагога в умовах відкритого інформаційно-навчального простору. Особливу увагу приділено аналізу інноваційних шляхів іï формування у навчальному процесі педагогічного університету.

Ключові слова: самоосвіта, компетентність самоосвіти, інформаційно-навчальне середовище, технологія, майбутній педагог.

Киселева О. Б. Инновационные пути формирования компетентности самообразования студентов в учебном процессе педагогического университета.

В статье рассмотрены сущность, структура компетентности самообразования будущего педагога в условиях открытой информационно-учебной среды. Особенное внимание уделено анализу инновационных путей формирования указанной компетентности в учебном процессе педагогического университета.

Ключевые слова: самообразование, компетентность самообразования, информационно-учебная среда, технология, будущий педагог.

Kyselyova O. B. Innovative ways of forming the self-educational competence of students in the educational process of a pedagogical university.

The article reviews the essence and structure of self-educational competence of a future teachers in the conditions of open informative-educational environment. The especial attention is directed on the analysis of innovative ways of its formation in educational process of a pedagogical university.

Key words: self-education, self-educational competence, informative-educational environment, technology, a future teacher.

В умовах динамічного розвитку інформаційного суспільства, конвергенції вітчизняної освіти зі світовим освітнім простором особливої актуальності набуває проблема формування нового покоління педагогічних кадрів, здатних до неперервного розширення світогляду, оволодіння новими високотехнологічними професійними інструментами, вдосконалення викладацької майстерності шляхом самоосвіти. Відповідно, тенденції розвитку вищої освіти зумовлюють зростання ролі самостійної роботи у професійному становленні студенті, інформатизація навчального процесу стимулює як удосконалення технологій викладання, так і оновлення способів учіння [0]. Провідним завданням сучасної системи педагогічної освіти постає формування у студентів педагогічного університету компетентності самоосвіти як цілісного багатокомпонентного професійно-значущого особистісного утворення, що відображає єдність готовності й здатності до ефективного здійснення самоосвіти з використанням новітніх форм із опорою на електронні навчальноінформаційні й освітні ресурси мережі Інтернет задля неперервного самовдосконалення щодо реалізації соціальних, особистісних та професійно-педагогічних функцій [2].

У працях багатьох сучасних дослідників (І. Зимня, О. Овчарук, О. Пометун, Дж. Равен, С. Раков, С. Шишов, А. Хуторський та інші) розкрито компетентнісний підхід як провідний напрям удосконалення національної системи освіти. У наукових доробках М. Бондаренка, Г. Коджаспірової, О. Малихіна, І. Наумченка, М. Рогозіної, Н. Сидорчук, Н. Терещенко, В. Шпак та інших висвітлено актуальні проблеми самоосвіти. Зростаючу роль самоосвіти в інформаційному суспільстві висвітлено А. Андрєєвим, В. Корвяковим, В. Надеїним, Є. Полат, Г. Сєріковим, М. Солдатенком, О. Шукліною та іншими, використання інформаційних технологій як засобу самоосвіти розглянуто Є. Ганіним, Ю. Калугіним, 
С. Яшановим та іншими. Однак поза увагою науковців залишаються такі аспекти окресленої проблеми: аналіз і запровадження в систему вітчизняної вищої педагогічної освіти інноваційного досвіду з підготовки майбутнього вчителя до самоосвітньої діяльності; пошук адекватних до вимог часу шляхів формування вмінь і навичок такої діяльності на засадах компетентнісного підходу; наукове обгрунтування, розроблення та створення дидактико-методичного забезпечення технології формування компетентності самоосвіти у студентів педагогічних спеціальностей у процесі їх професійної підготовки.

Метою статті є висвітлення інноваційних шляхів формування компетентності самоосвіти в навчальному процесі педагогічного університету.

В умовах сьогодення педагогічна освіта, будучи основою професійної підготовки майбутнього вчителя, стрімко розвиваючись, потребує впровадження інноваційних підходів розв'язання нагальних питань. Так, проблема формування компетентності самоосвіти майбутнього педагога вимагає попереднього з'ясування сутності самоосвіти, визначення її особливостей на сучасному етапі інформатизації суспільства, виокремлення сукупності тих знань і вмінь, набуття яких забезпечує успішність самоосвіти.

Самоосвіта майбутнього педагога $\epsilon$ добровільною, самостійною індивідуальнопізнавальною діяльністю, керованою особистістю та спрямованою на неперервне самовдосконалення реалізації соціальних, особистісних та професійно-педагогічних функцій [3, с. 7]. Аналіз результатів досліджень (М. Бондаренко, І. Грабовець, А. Громцева, І. Калошина, О. Малихін, Г. Сєріков, Н. Терещенко, В. Шпак та ін.) дозволив структурувати зміст самоосвіти та визначити етапи й відповідні кроки іiі реалізації: постановка мети, планування, організація, реалізація, рефлексія. Етап постановки мети передбачає виконання таких основних етапів: орієнтація (самопізнання, самооблік, самовизначення, самомотивація) та визначення мети з обов'язковим передбаченням кінцевого результату і засобів досягнення. Етап планування полягає у проектуванні особистістю конкретних дій, спрямованих на вдосконалення знань, умінь, певних якостей через самоосвіту й менеджмент часу, що сприяє економному використанню ресурсів і водночас ефективному розв'язанню поставлених завдань. Етап організації складається 3 ефективного пошуку необхідної інформації й раціонального налаштування робочого місця. Етап реалізації означає безпосереднє виконання окресленого щодо самовдосконалення знань, способів діяльності, певних якостей засобами самоосвіти. На етапі рефлексії здійснюється усвідомлення особистістю досягнутого в процесі самоосвіти результату, що передбачає самоконтроль, самооцінку, самоаналіз, самокорекцію. тощо.

На основі аналізу сучасної наукової літератури (Н. Бухлова, Т. Землінська, Н. Коваленко, І. Орлова, І. Преображенська, А. Радченко, Л. Чернікова, О. Фоміна та інші) з'ясовано сутність компетентності самоосвіти майбутнього педагога та виокремлено у структурі такі компоненти: мотиваційно-ціннісний, організаційний, процесуальноінформаційний та контрольно-рефлексивний [3, с. 8].

Із психологічної позиції компетентність самоосвіти майбутнього педагога має передумовою усвідомлення ним особистісної та суспільної цінності професійного самовдосконалення, реальної можливості досягнення результату 3 використанням інформаційно-комунікаційних технологій, внутрішню потребу в самоосвіті та позитивну мотивацію, розвинений емоційно-вольовий механізм щодо подолання труднощів тощо. Зазначені якості належать до мотиваційно-ціннісного компоненту досліджуваної дефініції, що суттєве значення протягом здійснення самоосвіти.

Організаційний компонент компетентності самоосвіти охоплює комплекс дій i відповідних умінь щодо визначення мети самоосвіти (близької й перспективної), раціонального іiі планування (самостійне визначення змісту, джерел пізнання, термінів виконання запланованого, передбачення ходу і результатів) та організації (побудова власної самоосвітньої траєкторії, з урахуванням індивідуальних потреб й здібностей, добирання адекватних форм і методів, регламентування та контроль часу тощо). 
Специфічні в контексті інформаційно-навчального середовища дії, що стосуються раціонального вибору інформаційно-пошукових систем, ефективного застосовування їх інструментів тощо (інформаційно-пошукові вміння), аналізу, систематизації інформації, оцінки ії вірогідності, релевантності тощо (інформаційно-аналітичні вміння), ефективного використання засобів інформаційно-комунікаційних технологій для опрацювання, інтегрування різноформатної інформації, створення інформаційних продуктів тощо (технологічні вміння), складають процесуально-інформаційний компонент компетентності самоосвіти майбутнього педагога.

Із позиції останнього етапу здійснення самоосвіти - рефлексії - важливим $\epsilon$ виокремлення контрольно-рефлексивного компоненту у структурі досліджуваної компетентності, що передбачає у майбутнього педагога вміння здійснювати самоконтроль i рефлексію (аналізувати, оцінювати власну самоосвіту, коригувати й розробляти нові подальші завдання), в єдності 3 використанням автоматизованих контрольнодіагностичних засобів.

Узагальнення результатів аналізу психолого-педагогічних досліджень щодо самоосвіти студентів (В. Буряк, Г. Сєріков, В. Шпак та інші) надає підстави для висновку про доцільність використання технологічного підходу як методологічної основи формування в майбутніх педагогів компетентності самоосвіти. Зазначений підхід ставить за мету сконструювати, відштовхуючись від вихідних установок, навчальний процес, який передбачає певну послідовність операцій із використанням оптимальних засобів, способів організації діяльності й умов іiі здійснення, спрямованих на забезпечення досягнення заданого результату.

У ході наукового пошуку розроблено інноваційну технологію формування компетентності самоосвіти студентів у навчальному процесі педагогічного університету, яка $\epsilon$ впорядкованою сукупністю дій, операцій і процедур, що інструментально забезпечують досягнення прогнозованого результату в межах компетентнісного підходу, спрямовують на ефективну майбутню педагогічну самоосвіту відповідно до особливостей в умовах інформаційно-навчального середовища, що полягають у відкритості й динамічності інформаційного простору самоосвіти, розширенні форм самоосвіти, відсутності часових і територіальних обмежень щодо іiі здійснення, варіативності самоосвітніх електронних навчально-інформаційних ресурсів, опосередкованості доступу до Інтернет-джерел, наявності додаткових можливостей для самоконтролю. Зазначена технологія оптимізує досвід самоосвіти студента й передбачає послідовну реалізацію етапів: пропедевтичного (адаптація студентів до інформаційно-навчального середовища, реалізованого у вищому навчальному закладі, формування в них окремих умінь, значущих для самоосвіти); базового (ініціювання самоосвіти, комплексне формування самоосвітніх умінь 3 опорою на використання інформаційно-комунікаційних технологій); продуктивного (накопичення майбутніми педагогами суб'єктивного досвіду самоосвіти).

На пропедевтичному етапі основними завданнями є оптимізація позитивної мотивації самоосвіти студентів; орієнтування щодо використання інформаційно-навчального середовища в самостійному навчанні; систематизація та поглиблення набутих у процесі загальноосвітньої підготовки вмінь пошуку й опрацювання інформації з використанням інформаційно-комунікаційних технологій; спонукання до самооцінювання власних знань та вироблення вмінь самоконтролю.

На усвідомлення студентами особистісної та професійної значущості самоосвіти, залучення їх до складання індивідуальних програм самоосвіти, розвиток сукупності інформаційно-пошукових, інформаційно-аналітичних, технологічних умінь та вмінь здійснювати контроль і аналіз процесу та результатів самоосвіти спрямовано базовий етап розробленої технології.

Наступний етап - продуктивний - передбачає інтеграцію потреби в самоосвіті 3 майбутньою педагогічною діяльністю; удосконалення вмінь самоосвіти, вироблених на 
попередніх етапах; залучення студентів до презентації результатів самоосвіти; стимулювання до визначення напрямів і шляхів подальшої самоосвіти [3].

У розробленні зазначеної інноваційної технології враховано такі провідні положення: мотивація самоосвіти студентів повинна мати усвідомлений характер; компетентність самоосвіти становить певну систему специфічних умінь і навичок, для формування яких потрібно використання адекватних засобів, що відповідають інноваційним освітнім тенденціям, рівню розвитку сучасного суспільства, техніки й технологій, у тому числі й інформаційних; іï формування повинно здійснюватися системно, за якої засвоєння предметних знань й оволодіння самоосвітніми вміннями здійснювалися б як єдиний процес; практичні дії з оволодіння самоосвітніми вміннями необхідно розглядати як операції, що допомагають студенту раціонального здійснення видів пізнавальної діяльності.

Процес формування компетентності самоосвіти майбутнього педагога $\epsilon$ взаємозв’язаною сукупністю заходів, які забезпечують ефективне здійснення повного циклу самоосвіти. Особливість розробленої технології полягає в неперервності формування компетентності самоосвіти упродовж усього терміну підготовки майбутнього вчителя (кваліфікаційний рівень «бакалавр»); послідовності й наступності процесу формування досліджуваної компетентності; опорі на діяльнісний підхід; узгодженості 3 програмами навчання. Згідно із запропонованою технологією компетентність самоосвіти майбутніх педагогів формується на основі набуття досвіду самостійних спроб і досягнень самоосвіти, переходу від виконання завдань самоосвітнього характеру до виникнення стійкої потреби в самоосвіті, вироблення індивідуальної самоосвітньої траєкторії, включення ії до способу життя.

Кожному етапу розробленої технології відповідає певний зміст навчання, який забезпечується навчальними дисциплінами 3 інформатичної («Сучасні інформаційні технології», «Педагогічна інформатика»), методичної підготовки («Методика навчання (профільної предметної дисципліни)»), а також упровадженням спецкурсу «Самоосвіта в умовах інформаційно-навчального середовища», проведенням тренінгів («Інтернет у самоосвіті», «Тайм-менеджмент самоосвіти») [3]. Варто зазначити, що вона може бути адаптованою та застосованою загалом для підготовки фахівців різних профілів. Мета, задачі етапів залишаються, проте, враховується професійна спрямованість у змістовному наповненні, характері завдань тощо.

Отже, виходячи із визначення сутності самоосвіти, етапів та особливостей ії здійснення в умовах сучасного інформаційно-навчального середовища визначено сутність та конкретизовано структуру компетентності самоосвіти, а також наведено теоретичне обгрунтування інноваційної технології формування у студентів зазначеної компетентності в навчальному процесі педагогічного університету.

Перспективами дослідження є виявлення взаємозв'язків між особистісно-професійним зростанням педагогів через самоосвіту та підвищення якості освіти й особистісного розвитку учнів; подальше вдосконалення навчально-методичного забезпечення розробленої технології у напрямку її адаптації для студентів різних профілів.

\section{Література}

1. Вища освіта України і Болонський процес, за ред. В. Г. Кремня. Авт. кол. : М. Ф. Степко, Я. Я. Болюбаш, В. Д. Шинкарук, та ін. - Тернопіль, 2004. - 243 с. 2. Кисельова О. Б. Сутність і критерії сформованості компетентності самоосвіти майбутнього педагога / О. Б. Кисельова // Педагогіка та психологія : [зб. наук. праць]. - Харків : ХНПУ імені Г.С. Сковороди, 2010. - Вип. 36. - С. 70-76. 3. Кисельова О. Б. Формування компетентності самоосвіти у майбутніх педагогів в умовах інформаційно-навчального середовища : автореф. дис. на здобуття наук. ступеня канд. пед. наук : спец. 13.00.09 «Теорія навчання» / О. Б. Кисельова. - Х., 2011. - 20 с. 